\title{
Isolation and Characterization of Chlorpyrifos Degrading Bacterial Isolates from Rice Soil
}

\author{
Sonali Priyadarshini* and Tushar Kanti Dangar
}

\author{
Laboratory of Soil Microbiology, National Rice Research Institute, \\ Cuttack- 753006, Odisha, India \\ *Corresponding author
}

\section{A B S T R A C T}

Soil represents one of the most diverse habitats for more than a thousand million bacterial species present on the earth. The maintenance of soil quality, fertility and structure is essential for the protection of the biodiversity and integrity of terrestrial ecosystems.

\section{Keywords}

Chlorpyrifos, Organophosphorus insecticide, Rice, Bacterial isolate, Bacillus sp.

Article Info

Accepted:

04 July 2017

Available Online:

10 September 2017
Introduction of anthropogenic chemicals into soil may have lasting effects on soil microbial activities and thus soil health. Chlorpyrifos is a broad spectrum organo phosphorus insecticide, displaying insecticidal activity against a wide range of insects and other arthropod pests. It is characterized as moderately toxic compound with acute oral $\mathrm{LD}_{50}=135-165 \mathrm{mg} \mathrm{kg}^{-1}$. Therefore, it was essential to determine the behaviour of chlorpyrifos in soil and to evaluate the responses of soil microorganisms to repeated application. This information will be useful for predicting the environmental fate of this widely used insecticide from continuous use and for understanding the potential adverse effects of intensive treatments with chlorpyrifos on general soil bacteria and biochemical properties. Hence this study was conducted with chlorpyrifos to evaluate its effect on soil bacteria Two bacterial strains capable of utilizing chlorpyrifos as a sole source of carbon and energy for growth were isolated $15 \mathrm{~d}$ after third treatment of chlorpyrifos which indicated the capability of soil microorganisms for degrading chlorpyrifos was formed during the experiments. The two bacterial strains capable of utilizing chlorpyrifos were isolates TB251 and TB252. These two bacteria were further studied for Identification and characterization. The two strains showed different results for the biochemical tests suggesting genetic diversity of the population.

\section{Introduction}

The use of synthetic pesticides as crop protection agents has become the widely accepted ecological weapon for higher crop production. With the restricted use of most of the organochlorine insecticides, the organophosphorus compounds are taking the major share of insecticide consumption in India (Adityachaudhury et al., 1997). Chlorpyrifos [O, O diethyl- O-(3, 5, 6trichloro-2-pyridyl) phosphorothioate], a phosphorothioate insecticide has been commercially used since 1960 s. It is a broad spectrum organophosphorus agricultural insecticide used worldwide (Cho et al., 2002) displaying insecticidal activity against a wide range of insects and other arthropod pests. Chlorpyrifos is intensively used for effective control of gall midge (Orseolia oryzae), leaffolder (Nappalocroas medinalis) and leafhopper (Nephotettix virescens) (Mallick et 
al., 1999). Its application on soil helps control termites (Reticulitermes spp., Coptotermes spp., Heterotermes spp.) (Sundaram et al., 1999). Chlorpyrifos is a broad-spectrum organophosphate insecticide and acaricide widely used for insect pest control on grain, cotton, fruit, nut, and vegetable crops, as well as lawns and ornamental plants, which has caused a wide range of soil contamination (EPA 1997).

Its environmental fate has been extensively studied, and its half- life in soil varies from 10 to 120 days (Getzin, 1981; Racke et al., 1988) resulting in 3, 5, 6-trichloro-2-pyridinol (TCP) as the major degradation product.

The extensive use of chlorpyrifos has led to widespread environmental pollution, resulting in serious damage to non-target species. The control of chlorpyrifos pollutants is of great importance because they are toxic and recalcitrant. The use of chlorpyrifos degrading bacteria for bioremediation of chlorpyrifos- contaminated sites has been proved to be the most potential clean- up method.

In the present investigation, attempts has been made to isolate, characterize and identify novel chlorpyrifos degrading bacteria capable of utilizing chlorpyrifos as sole source of carbon and energy from rice soil.

\section{Materials and methods}

\section{Glass wares}

The following glass wares were used for the study: conical flasks $(200 \mathrm{ml}, 500 \mathrm{ml})$, beakers $(250 \mathrm{ml}, 500 \mathrm{ml})$, bottle $(100 \mathrm{ml}, 1 \mathrm{~L})$, glass slides and L rods, test tubes $(10 \mathrm{ml})$, poly propylene bottles, volumetric flasks (50 $\mathrm{ml}, 100 \mathrm{ml}, 1 \mathrm{~L}$ ), funnels. The glass wares were used as per the requirement of different experiments.

\section{Sterilization of glass wares}

The glass wares were first washed properly using detergent and tap water. All the glass wares were then rinsed with distilled water and were allowed to dry. Then, the glass wares were sterilized in the hot air oven at $160{ }^{\circ} \mathrm{C}-180^{\circ} \mathrm{C}$ for $2-3 \mathrm{~h}$.

\section{Sterilization of culture media and reagents}

The culture media were prepared as per required amount using distilled water in conical flasks. The conical flasks were tightly plugged with non-absorbent cotton. The mouths of the flasks were then wrapped with brown paper and autoclaved for $15 \mathrm{~min}$ at 15 atm pressure and $121^{\circ} \mathrm{C}$.

\section{Soil sample}

Soil from rice-growing areas of NRRI experimental field was used for our investigation purpose. The soil sample was air dried and ground to pass through a $<2-\mathrm{mm}$ sieve prior use. Physico-chemical characteristics were determined by following the protocol of Sparks et al., (1996). The data are represented in table 1.

\section{Insecticide and chemicals}

A commercial formulation of $94 \%$ chlorpyrifos 20EC (Force, Nagarjuna chemicals, Hyderabad, India) was used for greenhouse and laboratory studies.

\section{The Green house pot experiment}

Experiments were conducted in green house to determine the response of soil microorganisms and enzymes to repeated applications of chlorpyrifos to soils either planted to rice or unplanted and maintained under flooded as well as field capacity. Earthenware pots measuring $25.5 \mathrm{~cm}$ (height) 
X $9.5 \mathrm{~cm}$ (diameter) were separately filled with $5 \mathrm{~kg}$ of soils. Twenty one days old rice seedlings (cv. Naveen) were transplanted with 4 hills of one plant each per pot. Phosphorus as a single super phosphate (SSP) and potassium as muriate of potash (MOP) at 30 mg.kg-1 soil each were applied to soils of all the pots as basal dressing. Nitrogen $(60 \mathrm{mg}$ $\mathrm{kg}^{-1}$ soil) was applied as urea to all the pots in three splits. There were two uniform replicated pots of each soil for each treatment (chlorpyrifos [CP] Treated or Untreated). The 16 pots planted to rice variety Naveen were maintained in green house under controlled temperature. The treatments viz. floodedplanted (FP), flooded unplanted (FUP), nonflooded planted (NFP), non-flooded planted (NFNP) with chlorpyrifos (+) or without chlorpyrifos (-) were taken in 2 replications (1 and 2) for each treatment. The flooded pots were watered at regular intervals (12 h) and the non- flooded plants were watered just sufficient for survival. Chlorpyrifos was also added at regular intervals (16 days) (Fig. 1).

\section{Isolation of chlorpyrifos degrading bacteria}

For a more convincing evidence of the microbial role in the accelerated degradation of the pesticide, attempts were made to isolate chlorpyrifos- degrading bacteria and then determine their ability to degrade it in pure cultures in MSM medium (Mallick et al., 1999; Das and Adhya, 2012) with slight modifications.

For enrichment, $10 \mathrm{ml}$ MSM medium containing chlorpyrifos $\left(10 \mu \mathrm{g} \mathrm{ml}^{-1}\right)$ was inoculated with $100 \mu \mathrm{l}$ suspension of chlorpyrifos treated flooded soil and incubated at $28{ }^{\circ} \mathrm{C}$ on an orbital shaker at 110 rpm. After complete disappearance of chlorpyrifos from the inoculated medium in about 5 to 10 days, $1 \mathrm{ml}$ of this medium was added to a fresh set of $10 \mathrm{ml}$ MSM medium supplemented with chlorpyrifos as sole source of carbon and energy and incubated for a further period of 5 days. This was repeated 4 times at 5 day interval for selective enrichment of chlorpyrifos degrading bacteria. After 4th transfer, sample fractions were withdrawn aseptically for each dilution and analyzed for chlorpyrifos residue by GLC after extraction with n-hexane.

After 5 days, $1 \mathrm{ml}$ of the inoculated medium was serially diluted up to $10^{-8}$ dilution. The maximum dilution from which chlorpyrifos disappeared completely in 5 days was spread plated on MSM medium supplemented with glucose $(1 \%)$, peptone $(0.1 \%)$, agar $(1.8 \%)$ and chlorpyrifos $\left(10 \mu \mathrm{g} \mathrm{ml}^{-1}\right)$. Distinct type of bacterial colonies appeared on the agar plate at $28{ }^{\circ} \mathrm{C}$. MSM medium $(10 \mathrm{ml})$ containing chlorpyrifos (as the sole source of carbon) was inoculated with individual colonies that appeared on the agar plates. Some distinct bacterial colony types showing exceptional degradation were selected. These bacteria were further purified by several transfers on plates containing MSM medium with glucose, peptone and chlorpyrifos.

\section{Characterization and identification of chlorpyrifos degrading bacteria}

The bacterial isolates capable of growing on chlorpyrifos medium were subjected to cultural, morphological, sugar utilization, biochemical and antibiotic assay. They were further identified by using standard methods (Krieg and Holt, 1984). Genomic DNA was isolated from bacterial cells grown overnight in MSM medium supplemented with glucose and peptone using CTAB method (Das and Adhya, 2012).

\section{Accelerated degradation of chlorpyrifos in the soils retreated with chlorpyrifos}

Bacterial suspension $(100 \mu \mathrm{L})$ was added to MSM medium containing $10 \mu \mathrm{g} / \mathrm{mL}$ chlorpyrifos which was further incubated at 
$28{ }^{\circ} \mathrm{C}$ on rotary shaker at $110 \mathrm{rpm}$. Uninoculated medium served as control. At periodic intervals each inoculated and uninoculated fractions were withdrawn aseptically from each duplicate sets and chlorpyrifos remaining in the medium was determined by Gas Liquid Chromatography (GLC) after extraction with n-hexane.

\section{Results and Discussion}

\section{Soil sample analysis}

The soil sample brought from NRRI, Odisha was analysed and the data represented in table 1 .

The soil sample was slightly acidic which corroborates with the findings of Das and Adhya (2015).

\section{Isolation of chlorpyrifos degrading bacteria}

Two bacterial isolate coded TB251 and TB252 were isolated capable of degrading chlorpyrifos within $10-12$ days using it as a sole source of carbon and energy. These two bacteria were further studied for Identification as well as characterization.

Simultaneously, bacterial cell number involving in chlorpyrifos degradation was measured. The un-inoculated control was nearly same after $12 \mathrm{~d}$ of incubation in mineral salt medium.

\section{Colony characters of the bacterial cultures}

The isolate TB 251 showed circular, gummy white, raised and entire margin colonies but isolate TB 252 colony was irregular, gummy white, raised and undulate. Diameter of the colonies ranged from 2.5-4.0 (TB 251) and 3.0-5.0 (TB 252) on NA after 3 days (Table 2).
Characteristics of vegetative cells, spores, crystals and staining characters of the bacterial cultures

The characteristics of vegetative cells and spores of TB isolates are given in tables 3 and 4 , respectively. Length and width of TB251 and 252 ranged from 3.3-5 x 1.1-1.3 $\mu \mathrm{m}$ and 3.9-5 x 1.2-1.4 $\mu \mathrm{m}$ respectively. Length and diameter of the spores ranged between 1.5$2.00 \times 1.0-1.5 \mu \mathrm{m}$ and $1.8-2.5 \times 1.0-1.4 \mu \mathrm{m}$ for $\mathrm{TB} 251$ and 252 respectively. All the bacteria were positive for Gram and spore stain. Characters of crystals and spore \& crystal property of the isolates are shown in tables 5 and 6 , respectively.

\section{Physiological and enzymatic activity of the isolates}

The physiological and enzymatic characters of the isolates are revealed in tables 7 and 8, respectively. The isolate TB251 showed growth at $4 \% \mathrm{NaCl}$ supplemented nutrient agar medium whereas TB252 showed tolerance up to $7 \% \mathrm{NaCl}$ concentrations. TB251 showed luxuriant growth at $0.6 \mathrm{M} \mathrm{Na}$ acetate and weak growth at $0.7 \mathrm{M}$ whereas TB252 showed good growth at $0.8 \mathrm{M} \mathrm{Na}$ acetate. Both the isolates were positive for gelatinase, casein hydrolysis, protease, lipase and lecithinase.

\section{Fermentation of organic carbon sources}

Fermentation reactions of both the organisms varied significantly (Table 9). Both of the bacteria fermented glucose, besides TB 251 fermented fructose and TB 252 fermented sucrose and esculin but none fermented mannose, starch, arabinose and xylose.

\section{Biochemical properties of the isolates}

Some of the physiological and biochemical properties of the isolates are presented in 
Table 10. The organisms were positive for catalase, methyl red and VP test but negative for indole production, citrate utilization and oxidase test. Other test results were variable for the two organisms.

Acid and gas production by the isolates from different carbon sources

Acid and gas production by both the isolates did not vary greatly (Table 11).

The organisms did not produce gas from any one of the carbon compounds. Both the organisms produced acid glucose, sucrose, arabinose, glycogen, galactose and fructose. TB 252 produced acid from glycerol but TB 251 was negative. None could grow in presence of citrate.

\section{Antibiotic sensitivity assay}

Response of the organisms to the recommended doses of different antibiotics (Table 12) showed that TB252 was sensitive to 16 out of 17 tested anibiotic i.e. nystatin. TB 251 isolate showed resistance to penicillin, ampicillin and nystatin too.

Fig.1 Photograph of pots in the net house

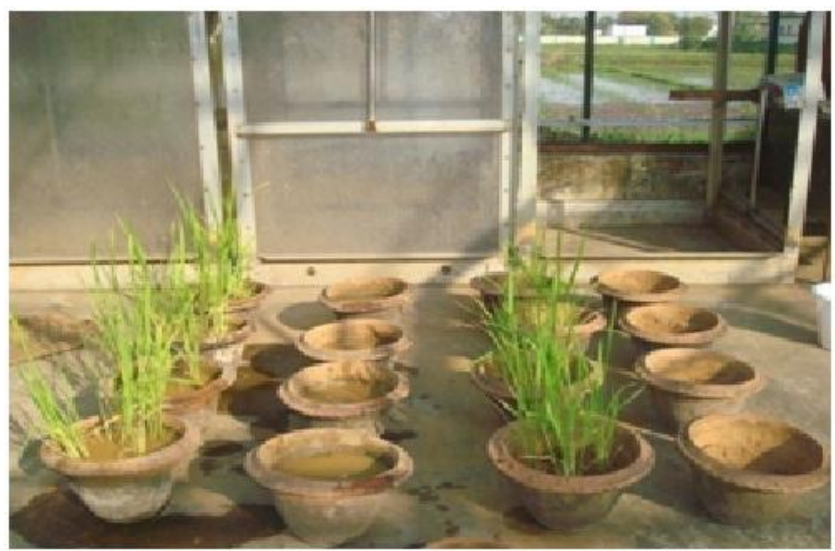

Fig.2 Agarose gel profile of plasmid and genomic DNA of TB isolates
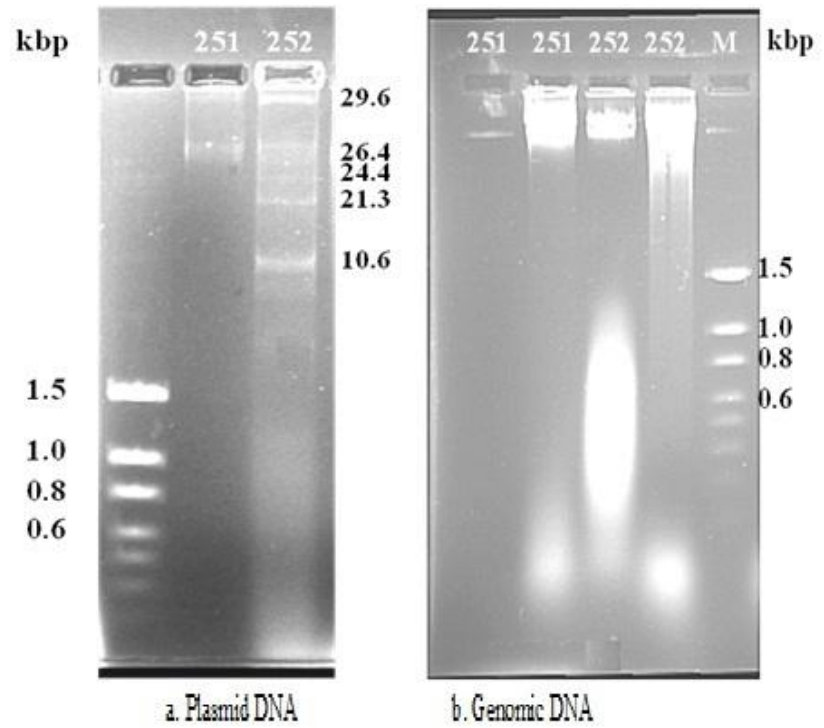
Fig.3 Degradation of chlorpyrifos by TB251

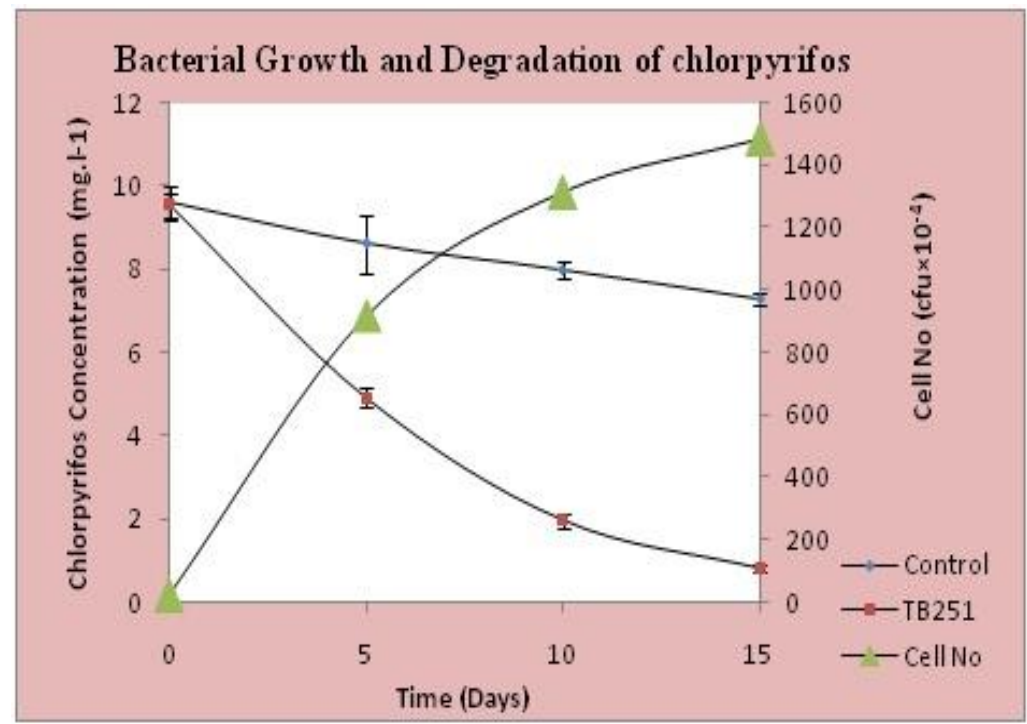

Fig.4 Degradation of chlorpyrifos by TB252

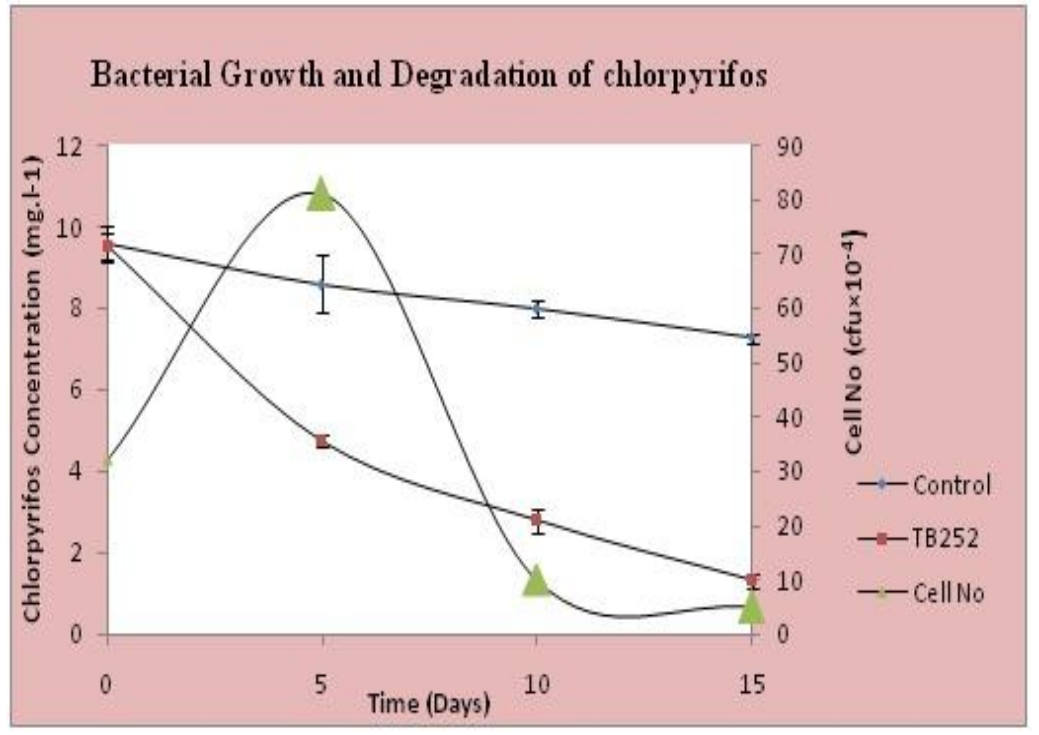

Table.1 Physico-chemical characterization of rice soil sample

\begin{tabular}{|l|l|l|l|}
\hline Location & Soil type & $\mathrm{pH}$ & $\mathrm{EC}\left(\mathrm{ds} \mathrm{m}^{-1}\right)$ \\
\hline NRRI, Odisha & Alluvial & 6.0 & 0.5 \\
\hline
\end{tabular}

Table.2 Colony characters of bacterial isolates on nutrient agar plates

\begin{tabular}{|c|c|c|c|c|c|}
\hline Bacteria no. & Form & Colour & Elevation & Margin & Size $(\mathrm{mm})$ \\
\hline TB 251 & Circular & Gummy white & Raised & Entire & $2.5-4.0$ \\
\hline TB 252 & Irregular & Gummy white & Raised & Undulate & $3.0-5.0$ \\
\hline
\end{tabular}

Results are from 10 colonies. 
Table. 3 Characters of vegetative cells of bacterial isolates

\begin{tabular}{|c|c|c|c|c|c|c|c|c|c|}
\hline \multirow{2}{*}{$\begin{array}{l}\text { Bacteria } \\
\text { no. }\end{array}$} & \multirow[t]{2}{*}{ Shape } & \multicolumn{3}{|c|}{ Length $(\mu \mathrm{m})^{*}$} & \multicolumn{3}{|c|}{ Breadth $(\mu \mathrm{m})^{*}$} & \multirow[t]{2}{*}{ Motility } & \multirow{2}{*}{$\begin{array}{l}\text { Gram } \\
\text { stain }\end{array}$} \\
\hline & & Range & Mean & $\pm \mathrm{SE}$ & Range & Mean & $\pm \mathrm{SE}$ & & \\
\hline TB 251 & $\begin{array}{c}\text { Rods with } \\
\text { rounded ends }\end{array}$ & $3.3-5$ & 4.16 & 0.54 & $1.1-1.3$ & 1.18 & 0.07 & Motile & + \\
\hline ТВ 252 & $\begin{array}{l}\text { Rods with } \\
\text { rounded ends }\end{array}$ & $3.9-5$ & 4.54 & 0.39 & $1.2-1.4$ & 1.28 & 0.07 & Motile & + \\
\hline
\end{tabular}

Table.4 Characters of spores of bacterial isolates

\begin{tabular}{ccccccccc}
\hline Bacteria & Shape & \multicolumn{3}{c}{ Length $(\square \mathrm{m})^{*}$} & \multicolumn{3}{c}{ Breath $(\square \mathrm{m})^{*}$} & \multirow{2}{*}{$\begin{array}{c}\text { Spore } \\
\text { no. }\end{array}$} \\
\cline { 3 - 7 } & & Range & Mean & $\pm \mathrm{E} \Sigma$ & Range & Mean & $\pm \mathrm{E} \Sigma$ & stain \\
\hline TB 251 & Oval & $1.5-2$ & 1.7 & 0.02 & $1.0-1.5$ & 1.25 & 0.15 & + \\
TB 252 & Oval & $1.8-2.5$ & 2.1 & 0.15 & $1.0-$ & 1.16 & 0.12 & + \\
& & & & & 1.4 & & & \\
\hline
\end{tabular}

$+=$ Positive result, ${ }^{*}$ Results of 10 observations.

${ }^{*}$ Total cells are 101 and 72 for TB 251 and 252, respectively

Table.5 Characters of crystals of bacterial isolates

\begin{tabular}{cccccc}
\hline \multirow{2}{*}{$\begin{array}{c}\text { Bacteria } \\
\text { no. }\end{array}$} & Shape & \multicolumn{3}{c}{ Diameter $(\mu \mathrm{m})^{*}$} & Crystal \\
\cline { 3 - 5 } & & Range & Mean & \pm SE & stain \\
\hline TB 251 & Irregular & $0.8-1.2$ & 1.05 & 0.27 & + \\
TB 252 & Irregular & $0.8-1.1$ & 0.93 & 0.27 & + \\
\hline + Positive result, & Results of 10 observations. & & &
\end{tabular}

$+=$ Positive result, ${ }^{*}$ Results of 10 observations.

Table.6 Spore and crystal production property of bacterial isolates

\begin{tabular}{llllc}
\hline Bacteria no. & \multicolumn{4}{c}{ Percentage of total cells } \\
\cline { 2 - 5 } & $\begin{array}{l}\text { Spore }+ \\
\text { one crystal }\end{array}$ & $\begin{array}{l}\text { Spore } \\
\text { only }\end{array}$ & $\begin{array}{l}\text { Crystal } \\
\text { only }\end{array}$ & $\begin{array}{l}\text { More than } \\
\text { one crystal }\end{array}$ \\
\hline TB 251 & 35 & 31 & 32 & 3 \\
TB 252 & 27 & 23 & 22 & 0 \\
\hline
\end{tabular}

*Total cells are 101 and 72 for TB 251 and 252, respectively. 
Table.7 Physiological characteristics of Bacterial isolates

\begin{tabular}{|c|c|c|}
\hline \multirow{2}{*}{$\begin{array}{l}\text { Growth } \\
\text { medium }\end{array}$} & \multicolumn{2}{|c|}{ Bacterial isolate code } \\
\hline & TB 251 & TB 252 \\
\hline NA & + & + \\
\hline \multicolumn{3}{|c|}{$\mathrm{NA}+$ Sodium chloride $(\%)$} \\
\hline 1 & + & + \\
\hline 2 & + & + \\
\hline 3 & + & + \\
\hline 4 & + & + \\
\hline 5 & - & + \\
\hline 6 & - & + \\
\hline 7 & - & + \\
\hline 8 & - & - \\
\hline \multicolumn{3}{|c|}{$\mathrm{NA}+$ Sodium acetate $(\mathrm{M})$} \\
\hline 0.1 & + & + \\
\hline 0.2 & + & + \\
\hline 0.3 & + & + \\
\hline 0.4 & + & + \\
\hline 0.5 & + & + \\
\hline 0.6 & + & + \\
\hline 0.7 & $+(\mathrm{w})$ & + \\
\hline 0.8 & - & + \\
\hline MBA & - & - \\
\hline \multicolumn{3}{|c|}{ Anaerobic growth in NB } \\
\hline $\begin{array}{l}\text { Surface growth } \\
\text { on NB }\end{array}$ & Membranous & Membranous \\
\hline
\end{tabular}

Table.8 Enzymatic activities of different bacterial isolates

\begin{tabular}{lcc}
\hline Tests & Bacterial isolate designation \\
\cline { 2 - 3 } & TB 251 & TB 252 \\
\hline Gelatinase & + & + \\
Lipase & + & + \\
Casein hydrolysis & + & + \\
Amylase: & + & - \\
Protease & + & + \\
Tributyrin hydrolysis & - & - \\
Tween 80 hydrolysis & - & - \\
Cholesterol hydrolysis & - & - \\
Lecithinase & + & + \\
Chitin Hydrolysis & - & - \\
\hline
\end{tabular}

$+=$ Positive result, - = Negative result, Pectin hydrolysis could not be done. 
Table.9 Fermentation/utilization of organic carbon sources

\begin{tabular}{lcc}
\hline $\begin{array}{l}\text { Carbon } \\
\text { source }(1 \%)\end{array}$ & \multicolumn{2}{c}{ Bacteria No } \\
\cline { 2 - 3 } & TB251 & TB252 \\
\hline Glucose & + & + \\
Fructose & + & - \\
Mannose & - & - \\
Sucrose & - & + \\
Starch & - & - \\
Esculin & - & + \\
Arabinose & - & - \\
Xylose & - & - \\
& $-=$ Positive result, - = Negative result.
\end{tabular}

Table.10 Some biochemical properties of bacterial isolates

\begin{tabular}{lcc}
\hline \multirow{2}{*}{ Tests } & \multicolumn{2}{c}{ Bacteria No } \\
\cline { 2 - 3 } & TB 251 & TB 252 \\
\hline Catalase & + & + \\
Arginine dihydrolase (ADH) & + & - \\
production & & \\
Methyl red test & + & + \\
Indole production & - & - \\
Vogues-Proskauer (AMC) test & + & + \\
Nitrate reduction & - & + \\
Urease production & - & + \\
Citrate utilization & - & - \\
Oxidase & - & - \\
\hline Pitive result, - = Negative result, AMC = acetyl methyl carbinol.
\end{tabular}

Table.11 Acid and gas production by the isolates from different carbon sources

\begin{tabular}{lcccc}
\hline Carbon & \multicolumn{5}{c}{ Bacteria number } \\
source & TB 251 & \multicolumn{3}{c}{ TB 252 } \\
\cline { 2 - 5 } & Acid & Gas & Acid & Gas \\
\cline { 2 - 5 } Glucose & + & - & + & - \\
Sucrose & + & - & + & - \\
Arabinose & + & - & + & - \\
Glycogen & + & - & + & - \\
Citrate & - & - & - & - \\
Galactose & + & - & + & - \\
Glycerol & - & - & + & - \\
Fructose & + & - & + & - \\
\hline + = Positive result, - = Negative result &
\end{tabular}


Table.12 Antibiotic assay of different Bacillus sp. isolates

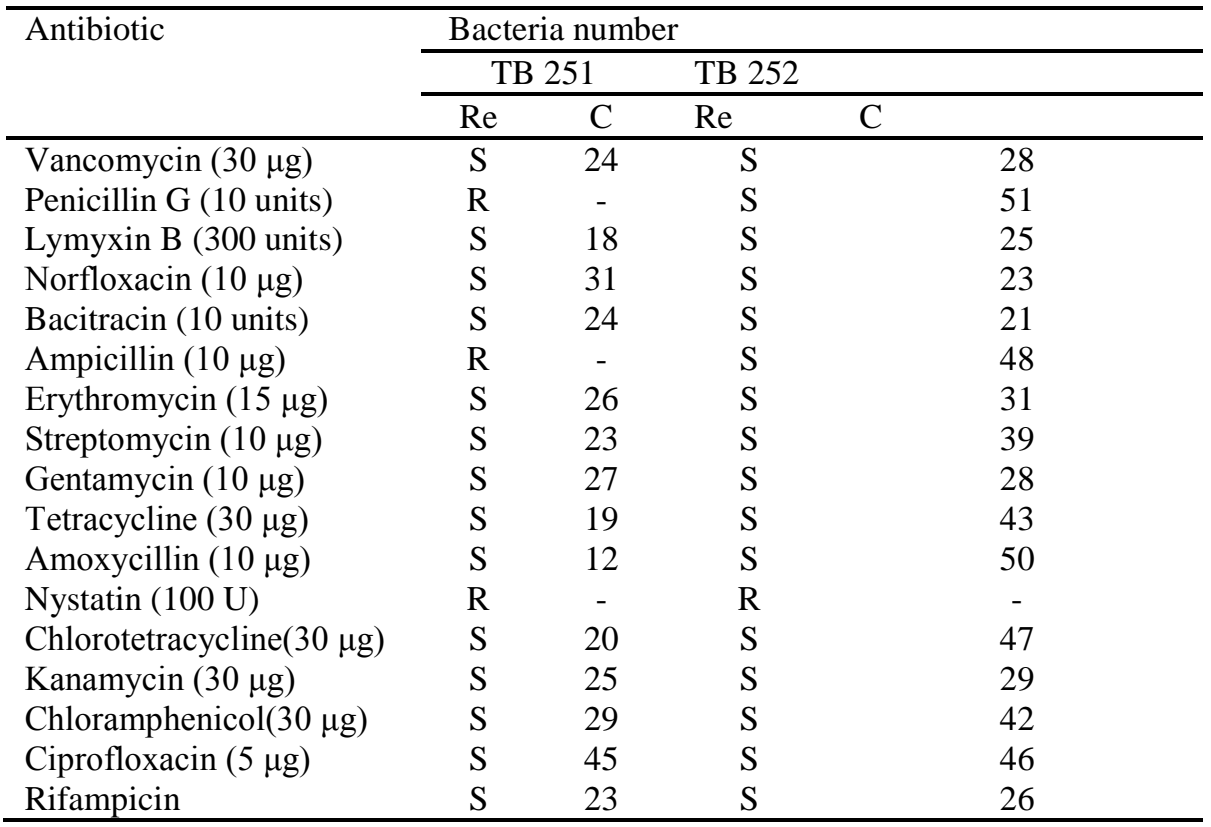

$\mathrm{Re}=$ Reaction, $\mathrm{C}=$ Clear zone diameter in $\mathrm{mm}, \mathrm{S}=$ Sensitive, $\mathrm{R}=$ Resistant.

Table.13 Identification scheme of the isolates up to genus and Species level based on some basic characters

\begin{tabular}{lcc}
\hline Characters & \multicolumn{3}{c}{ Bacteria isolate code } \\
\cline { 2 - 3 } & TB251 & TB252 \\
\hline Shape & Rod & Rod \\
\hline Length $(\mu \mathrm{m})$ & 4.16 & 4.54 \\
\hline Width $(\mu \mathrm{m})$ & 1.18 & 1.28 \\
\hline Sporangium & Not swollen & Not swollen \\
\hline Spore & Oval & Oval \\
\hline Crystal & Irregular & Irregular \\
\hline Gram stain & + & + \\
\hline Catalase activity & + & + \\
\hline Oxidase activity & - & - \\
\hline Anaerobic growth & - & - \\
\hline Melting temperature $(\mathrm{Tm})\left({ }^{\circ} \mathrm{C}\right)$ & ND & ND \\
\hline (G+C)\% & ND & ND \\
\hline Genus & Bacillus sp. & Bacillus sp. \\
\hline
\end{tabular}

$+=$ Positive result, $-=$ Negative result, $\mathrm{ND}=$ Not done.

\section{Identification of the isolates}

Comprehensive results of biochemical characters of the isolates for identification upto genus level are presented in table 13.

Both the isolates were Gram positive and spore forming rods, width of rods was $>0.9$ $\mu \mathrm{m}$, catalase positive and sporangium was not swollen. Both of the organisms did not grow anaerobically. Both the organisms produced acetyl methyl carbinol (AMC). TB 251 produced arginine dihydrolase. TB 252 fermented esculin, sucrose, produced urease but both of them were negative for citrate utilization. 
Agarose gel electrophoresis profile of plasmids of the isolates

The isolates viz. TB 251 and 252 were checked for their plasmid compositions (Fig. 2). TB 251 produced 2 bands at about 29.6 and $26.4 \mathrm{kbp}$ while TB 252 produced 5 bands at 29.6, 26.4, 24.4, 21.23 and $10.6 \mathrm{kbp}$ positions. Both the organisms contained the mega plasmid of $29.6 \mathrm{kbp}$ size.

\section{Growth and degradation ability of the two bacterial isolates}

Degradation pattern of the two bacterial strains was studied in liquid culture medium supplemented with chlorpyrifos as the sole carbon source. The time period of degradation of chlorpyrifos is shown at figures 3 and 4 respectively.

Singh et al., (2003) reported about the degradation of chlorpyrifos in the Australian soil. The action was strongly related to soil $\mathrm{pH}$, and degradation was microbial and not due to abiotic hydrolysis. Chlorpyrifosdegrading bacterium was isolated from this soil that showed complete degradation. Yang et al., (2005) isolated a bacterium from contaminated soils around a chemical factory and named the strain DSP3 which was capable of biodegrading both chlorpyrifos and 3, 5, 6-trichloro-2-pyridinol. The strain DSP3 was identified as Alcaligenes faecalis. Chlorpyrifos was utilized as the sole source of carbon and phosphorus by strain DSP3. Jespa and Kanagappan (2015) highlighted a bacterial species of Staphylococcus which is a native bacterium growing on the chlorpyrifos contaminated soil. The isolate was utilized to degrade the chlorpyrifos mixed in the broth medium.

The two bacterial isolates TB251 and TB252 isolated from chlorpyrifos retreated rice soil were capable of degradation within 10 to 15 days. Bacillus spp. isolated from rice soil was diverse in nature. The isolate TB251 was resistant to penicillin group of antibiotics but TB 252 was sensitive to all most all of the antibiotics except nystatin. Agarose gel electrophoresis depicted 2-5 plasmid bands. Chlorpyrifos is as an important agent for the control of plant pathogens however it should not be used at rates much greater than the recommended dosage. The pathway for degradation of chlorpyrifos and identifying the genes and enzymes responsible for this process require further investigation.

\section{Acknowledgement}

The authors are grateful to Dr. T. K. Adhya, former Director, NRRI, Cuttack for permitting to conduct research work in this highly esteemed institution. The authors have no conflict of interest to declare.

\section{References}

Adityachaudhury, N., Banerjee, H., and Kole, R. K. 1997. An appraisal of pesticide use in Indian agriculture with special reference to their consumption in West Bengal. Sci Cult, 63: 223-228.

Cho, C.M., Mulchandani, A., and Chen, W. 2002. Bacterial cell surface display of organophosphorus hydrolase for selective screening of improved hydrolysis of organophosphate nerve agent. Appl Environ Microbiol, 68: 2026-2030.

Das, S., and Adhya, T.K. 2012. Isolation and characterization of a chlorpyrifos degrading bacterium from rice soil. Plant Sci Res, 34 (1\&2): 17-22.

Das, S., and Adhya, T.K. 2015. Degradation of Chlorpyrifos in tropical rice soils. $J$ Environ manage, 152:36-42.

EPA, 1997. Review of chlorpyrifos poisoning data. EPA, Washington, DC.

Getzin, L.W., 1981. Degradation of 
chlorpyrifos in soil: influence of autoclaving, soil moisture, and temperature. J Econ Entomol., 74: 158162.

Jespa, J.P., and Kanagappan, M. 2015. Biodegradation of chlorpyrifos using Staphylococcus sp isolated from the Rhizospere of Calotropis gigantea r.Br. Sch. Acad. J. Biosci, 3(10): 828-832.

Krieg, N.R. and Holt, J.C. (eds., 1984). Bergey's Manual of Systematic Bacteriology, 1st ed., vol. 1, Williams and Wilkins, Baltimore.

Mallick, B.K., Banerji, A., Shakli, N.A., and Sethunathan, N.N. 1999. Bacterial degradation of chlorpyrifos in pure culture and in soil. Bull Environ Contam Toxicol., 62: 48-55.

Racke, K.D., Coats, J.R. and Titus, K.R. 1988. Degradation of chlorpyrifos and its hydrolysis products, 3, 5, 6-trichloro2-pyridinol in soil. J Environ Sci Health B. 23: 527-539.
Singh, B.K., Walker A, Morgan J.A.W, and Wright DJ. 2003. Effects of Soil pH on the biodegradation of chlorpyrifos and isolation of a chlorpyrifos-degrading bacterium. Appl Environ Microbiol. 69(9): 5198-5206.

Sparks, D.L., Page, A.L., Summer, M.E., Tabatabai, M.A., and Helmke, P.A. 1996. Methods of soil Analysis, Part 3, Chemical Methods. American Society of Agronomy, USA, 1358.

Sundaram, B., Rai, S.K., Ravendra, N., 1999. Degradation of bifenthrin, chlorpyrifos and imidacloprid in soil and bedding materials at termiticidal application rates. Pesticide Sci. 55, 1222-1228.

Yang, Li., Zhao, Yu-hua., Zhang, Bing-xin., Yang, Ching-Hong., and Zhang, Xin. 2005. Isolation and characterization of a chlorpyrifos and 3, 5, 6-trichloro-2pyridinol degrading bacterium FEMS Microbiol Lett. 251:67-73.

\section{How to cite this article:}

Sonali Priyadarshini and Tushar Kanti Dangar. 2017. Isolation and Characterization of Chlorpyrifos Degrading Bacterial Isolates from Rice Soil. Int.J.Curr.Microbiol.App.Sci. 6(9): 329-340. doi: https://doi.org/10.20546/ijcmas.2017.609.042 